\title{
ANALISIS PENGARUH HARGA DAN KUALITAS LAYANAN ELEKTRONIK TERHADAP KEPUASAN KONSUMEN PADA PENGGUNA APLIKASI SHOPEE
}

\author{
Oktavianus Chrisnamurti Sabda Putra Mediti \\ Universitas Negeri Surabaya \\ oktavianusmediti@mhs.unesa.ac.id
}

Abstract

\begin{abstract}
The internet could be used as a means of online trading which is why often referred to as e-commerce (electronic commerce). The increasingly positive e-commerce growth in Indonesia has resulted in a shift in people's shopping patterns towards online or online shopping, thus making marketers learn various strategies so that consumers continue to feel satisfaction when shopping using applications, especially Shopee online shop applications. The purpose of this research is to analyze consumer satisfaction as measured by the price and eservice quality. The population in this study are respondents with a minimum age of 15 years who is infinite and has to carry out payment of at least 1 time in the last 6 months Shopee application. The sampling techniques used are non-probability sampling by sampling method i.e. judgmental sampling and obtained as much as 220 respondents. The technique of data collection for this research uses online questionnaire distribution with a Likert scale and the technical analysis of the data used is multiple linear regression. The results of this study show that the price and quality of e-service have a positive and significant influence on customer satisfaction variables in Shopee application users.
\end{abstract}

Keywords: price; e-service quality; satisfaction; Shopee.

\section{PENDAHULUAN}

Perkembangan digitalisasi seperti sekarang ini dalam informasi dan teknologi begitu cepat, sehingga menimbulkan ketatnya persaingan dalam berbisnis. Sehingga membuat para pelaku bisnis berpikir lebih luas, inovatif dan kreatif terhadap perkembangan ini, baik dibidang ekonomi, sosial, politik maupun budaya. Perkembangan industri e-commerce yang sangat cepat di Indonesia ditunjukkan dengan semakin banyak online shop dan marketplace yang muncul secara agresif (cnnindonesia.com, 2020).

Menurut Kotler (2008: 132), e-commerce merupakan penyelenggaraan bisnis perusahaan menggambarkan elektronik bisnis dengan penggunaan alat dan kerangka dasar elektronik. Penjualan menggunakan elektronik atau internet berati perusahaan yang menggunakan situs untuk menawarkan, berinteraksi ataupun memfasilitasi penjualan product atau service secara online. Menurut Rhee'q (2012: 39), olshop (online shop) yaitu penjualan yang dilaksanakan menggunakan internet dan tidak ada pertemuan dari penjual maupun pembeli. metode dalam memasarkan produk yang dijual yaitu dengan menggunakan gambar ataupun video ke sebuah web, jejaring sosial media ataupun aplikasi penjualan. Belanja menggunakan aplikasi online shop memiliki keunggulan dan kekurangan. Keunggulan dalam melakukan belanja dengan menggunakan aplikasi olshop (onlineshop) yaitu tidak harus keluar dari rumah dan memanfaatkan jaringan internet untuk mencari barang atau jasa untuk dibeli, dalam berkomunikasi dengan cara memakai alat komuniksi selain teknologi komputer contohnya seperti handphone. Barang diantar sampai kerumah menggunakan jasa pengiriman. Sedangkan kekurangannya yaitu tidak bisa melihat secara langsung kualitas dan bahan apa yang di pakai, melakukan pembayaran dahulu, kemudian barang akan dikirim ke pembeli, dan akan ada penipuan yang dilakukan oleh para olshop yang tidak bertanggungjawab pada aplikasi belanja elektronik yaitu kualitas pada sebuah website terutama Shopee dapat dilihat melalui pada saat konsumen ada di dalam sebuah situs.

Total kunjungan atau visit dan waktu kunjungan e-commerce pada tahun 2019, Tokopedia $150.63 \mathrm{M}$ dengan total visit dan dengan durasi kunjungan 04:09. Bukalapak 95.02 M dengan total visit dan dengan durasi kunjungan 04:56. OLX 43.18 M dengan total visit dan dengan durasi kunjungan 08:25. 
Shopee 30.51 M dengan total visit dan dengan durasi kunjungan 08:38 (Andrew, 2019). Kejadian tersebut menunjukan total visit shopee masih kurang baik dari e-commerce yang lain seperti OLX, Bukalapak, dan Tokopedia. Sedangkan Shopee memiliki durasi kunjungan paling lama dari $e$ commerce lainnya. Hal lainnya dikaitkan dengan beberapa masalah sebagai contoh terdapat beberapa kasus yang berkesinambungan dengan kualitas layanan elektronik pada platform shopee pada android maupun ios. Hal tersebut bisa berdampak pada biaya yang dilakukan pembeli pada aplikasi $e$ commeerce Shopee (inet.detik.com, 2019).

Beberapa masalah keluhan yang diberikan pada pemakai aplikasi Shopee. Masalah keluhan pada pengguna aplikasi Shopee yang di ambil sampelnya pada penelitian ini terjadi pada tahun 2019 yaitu pada tanggal 3 januari keluhannya penjual tidak merespon dan transaksi shopee tidak batal secara otomatis, pada tanggal 10 januari, tiga kali debit dan belum dikembalikan, pada tanggal 14 maret 2019, yaitu transaksi Shoppe dengan ATM BCA, ditagihnya dua kali, dan pada tanggal 3-mei, pesanan dari Shopee sudah di-cancel dan masih saja tertagih dalam kartu kredit (NewsDetik, 2019).

Keluhan yang disampaikan konsumen berkaitan dengan kualitas layanan elektronik pada aplikasi Shopee. Kasus-kasus tersebut tidak sampai mengejutkan atau viral di media sosial, tetapi kasus atau keluhan tersebut dapat menandakan bahwa kualitas layanan elektronik tersebut masih kurang dan perlu ditingkatkan lagi. Hal tersebut dapat berdampak pada kelangsungan operasional perusahaan juga kualitas layanan elektronik tersebut tidak di perbaiki. Maka itu kualitas layanan elektronik perlu ditingkatkan agar tercapainya kepuasan konsumen. Adanya keluhan atau kasus tersebut perlu di teliti lebih lanjut apakah kualitas layanan elektronik pada aplikasi Shopee sudah baik atau belum. Mengutip dari iprice, Shopee dinyatakan sebagai e-commerce yang sangat populer di Asia Tenggara dalam periode Kuartal 2 tahun 2019 dari segi aktivitas aplikasi, jumlah unduhan, serta jumlah transaksi di pasar regional dan keunggulan Shopee tersebut mengalahkan Lazada yang merupakan aplikasi $e$ commerce yang aktif (Iprice.co.id, 2019).

Kepuasan konsumen membuat suatu hal positif yang dapat dirasakan oleh konsumen yaitu hasil dari semua evaluasi terhadap pengalaman yang dirasakan pembeli setelah melakukan pembelian (Cronin, et al., 2000). Menurut Kandulapati \& Bellamkonda (2014), adanya 2 konsep yang umum supaya konsumen merasa puas yaitu rasa puas konsumen dalam bertransaksi (individu/ diri sendiri) dan rasa puas konsumen dalam kepuasan komulatif (semua pengalaman konsumsi konsumen). Pelayanan yang anda berikan akan dinilai oleh pelanggan dan bukan tidak mungkin akan ceritakan kepada orang lain, maka pelayanan baik yang berikan kepada pelanggan mampu mengurangi penilaian atau perkataan negatif dari pelanggan, yang dibicarakan dibelakang adalah hanya mengenai pelayanan anda yang baik kepada mereka. Kepuasan pelanggan dapat dijadikan sebagai bahan review seberapa besar kesenangan mereka berbelanja di toko, dengan begitu akan mengetahui pada bagian mana pelayanannya harus tingkatkan lagi agar perkembangan bisnis menjadi semakin baik lagi.

Kepuasan konsumen pastinya bukan hanya disambungkan dengan kualitas layanan tetapi mendapatkan faktor berbeda dalam mengaruhi kepuasan konsumen seperti harga yang telah menjadi faktor paling utama yang memengaruhi dalam pembelian (Kotler dan Armstrong, 2008:345). Sedangkan harga yang dikatakan oleh Kotler \& Keller $(2007 ; 156)$, harga merupakan beberapa jumlah uang atau nilai yang digunakan untuk mendapatkan memperoleh kemistri sebuah produk atau jasa yang mengikutinya.

Harga adalah salah satunya indikator pembeda untuk pembeli dalam pemilihan produk dan jasa. Kesamaan harga yang diberikan perusahaann atas pemilihan produk dan jasa akan membuat kepuasan pada konsumen. Sedangkan pada beberapa pemilihan produk dan jasa dengan kualitasnya yang tidak jauh beda, namun dengan adanya harga yang berbeda pembeli ingin condong untuk menentukan pilihan produk barang ataupun jasa atas harga dapat dijangkau konsumen (media.neliti.com, 2015). Menurut Swastha dan Irawan (2005:241), sejumlah nilai atau uang untuk mendapatkan yang dibutuhkan kemistri dari product and service. harga menurut Kotler \& Amstrong (2008:345) yaitu jumlah nilai atau uang yang dibayarkan atas barang ataupun jasa. Bisa juga 
Oktavianus Chrisnamurti Sabda Putra Mediti. Analisis Pengaruh Harga dan Kualitas Layanan Elektronik terhadap Kepuasan Konsumen pada Pengguna Aplikasi Shopee

sejumlah dari nilai tukar untuk para pelanggan dalam rangka mendapatkan kegunaan dari memiliki barang maupun jasa.

Menurut Parassuraman et.al (2005:217), kualitas layanan elektronik atau disebut juga e-service quality seperti dalam situs web memberikan fasilitas pembelanjaan sampai kepengiriman secara efektif dan efisien. Dampak langsung yang dialami dari kualitas layanan elektronik adalah rasa kepuasan atau tidak merasakan kepuasan dari layanan yang diberikan. Kotler dan Keller, (2009:138139) menjelaskan kepuasan yaitu timbulnya rasa senang atau kecewa karena membedakan kinerja yang dipikirkan produk terhadap keinginan mereka. Menurut Sumarwan (2014;387), rasa puas akan menimbulkan dorongan konsumen untuk melakukan pembelian lagi terhadap product tersebut atau sebaliknya, ketika konsumen tidak merasa puas dan kecewa maka hal ini menyebabkan konsumen untuk menghentikan belanjanya dan konsumsi mereka terhadap product tersebut.

Penelitian ini bertujuan dalam menganalisis dan juga membahas pengaruh harga dan kualitas layanan elektronik terhadap kepuasan konsumen pada pengguna aplikasi Shopee.

\section{KAJIAN PUSTAKA DAN PENGEMBANGAN HIPOTESIS}

\section{Perilaku Konsumen}

Sumarwan (2014:4) menjelaskan bahwa konsumen yang berperilaku selama proses pencarian, pembelian, pada saat menggunakan, melakukan evaluasi, serta pada saat konsumen menghabiskan produk atau jasa yang mereka harapkan dapat memberikan kepuasan terhadap apa yang mereka butuhkan. Berdasarkan penelitian yang dilakukan (Engel et al, 1995), suatu perilaku memiliki peran dalam proses untuk mendapatkan, menkonsumsi, serta menyelesaikan produk dan jasa, yang didahului oleh sistem keputusan dan kemudian perilaku mengikuti. Maka perilaku konsumen yaitu bentuk keseluruhan dari kegiatan yang mampu memberikan dorongan untuk melakukan tindakan pada kegiatan melakukan transaksi, ketika memakai, dan juga ketika menghabiskan produk maupun jasa yang kemudian setelahnya dilakukan evaluasi. Perilaku konsumen menjelaskan tindakan konsumen dalam mengkonsumsi product atau service dengan pendapatan tertentu dan harga produk atau jasa tertentu pula sedemikian rupa supaya konsumen mencapai tujuannya.

\section{Harga}

Berdasarkan penelitian yang dilakukan oleh Tjiptono (2018), harga adalah sejumlah uang dan jasa atau barang barang yang tersedia ditukarjan oleh pembeli untuk mendapatkan bebagai pilihan produkproduk dan jasa-jasa yang disediakan penjual. Harga produk yang terjual di pasar modern/online maupun tradisional tidak ada perbedaan yang cukup besar. Tetapi di dalam pasar tradisional konsumen dapat melakukan tawar menawar produk dan mencapai jalan tengahnya dengan para penjual dan sedangkan di dalam pasar modern/ online, konsumen tidak dapat melakukannya seperti di pasar tradisional karna di dalam pasar modern/ online, harganya pas sesuai yang tertera atau yang dipatok oleh penjual.

Sebanyak nilai atau uang yang diberikan pada satu produk baik barang ataupun jasa dapat disebut sebagai harga atau nilai yang pembeli harus bayar untuk mendapatkan manfaat produk tersebut, (Kotler dan Armstrong, 2001). Harga biasanya bertujuan sebagai indikator nilai atau uang apabila harga itu berhubungan dengan manfaat atau kegunaan yang diterima dari sebuah barang ataupun jasa. Demikian dapat artikan harga pada klasemen tertentu bilamana kegunaan yang dirasakan pembeli atau konsumen bertambah dan nilainya juga bertambah (Tjiptono, 2005). Harga dalam penelitian ini mengadopsi penelitian Hermin \& Faizi (2017), Faiziyah \& Purwadiani (2018), Hadita (2019), Noto \& Hakim (2016), dan Tangguh et.al. (2018), yaitu keterjangkauan harga, kesesuaian harga dengan manfaat, daya saing harga, dan kesesuaian harga dengan kualitas produk.

\section{Kualitas Layanan Elektronik}

Kualtas layanan elektronik (e-service quality) didefiniskan seberapa jauh sebuah situs atau aplikasi mampu memberikan fasilitas kegiatan dalam berbelanja yang konsumen lakukan didalam situs web atau aplikasi dapat berjalan secara lancar, efektif dan efisien, serta dalam hal pengiriman produk dan 
layanannya. Sebuah pelayanan yang memiliki sifat komperhensif menampung dari ke dua hal, yang pertama pralayanan dan yang kedua pada situs web (Parasuraman et al, 2005).

Pengukuran variabel kualitas layanan elektronik (e-service quality) dalam penelitian ini mengacu pada Hidayat \& Setyorini (2018), Awaliyah \& Saino (2012), dan Setyasworo \& Arsanti (2015) yang disesuaikan dengan obyek yang diteliti, yaitu efisien (effieciency), pemenuhan (fulfillment), ketersediaan sistem (system availability), dan privasi (privacy). Dengan kata lain, e-service quality merupakan keseluruhan dari karakteristik produk dan jasa, dalam penyampainnya kepada para konsumen dalam melayani kegiatan belanjanya, pembelian serta distribusi baik secara efisien dan efektif agar mampu memenuhi kebutuhan konsumen.

\section{Kepuasan Konsumen}

Kepuasan pelanggan ialah tingkat perasaan sebagai bentuk evaluasi dari konsumen kepada apa yang telah diterima atas kinerja produk jasa yang dapat memaksa konsumen dalam melakukan pembelian ulang maupun tidak. Kepuasan yaitu senang ataupun kesal yang timbul dalam membedakan produk sebenarnya terhadap ekspektasi konsumen (Kotler \& Keller, 2009;138-139). Kepuasan pelanggan memiliki dampak begitu signifikan terhadap beberapa aspek seperti minat beli ulang, loyalitas pelanggan, perilaku komplain, dan perilaku word of mouth positif (Tjiptono \& Chandra, 2012).

Berdasarkan jurnal yang diambil dari penelitian ini, maka dalam pengukuran variabel (kepuasan konsumen (satisfaction) menggunakan jurnal dari penelitian Indriyani \& Helling (2018), Fiazisyah \& Purwidiani (2018), dan Hermina \& Pauzi (2017) yang telah disesuaikan dengan obyek yang diteliti, maka peneliti ini menggunakan indikator minat berkunjung kembali, pembelian ulang, menciptakan WOM (word of mouth) dan indikator sesuai dengan harapan. Sehingga, kepuasan pelanggan ialah tingakat perasaan sebagai bentuk evaluasi dari konsumen terhadap apa yang diterima atas kinerja produk jasa yang dapat mendorong konsumen untuk mengkonsumsi ulang atau tidak.

\section{Hubungan antar Variabel}

Hermina \& Pauzi (2017) mengatakan bahwa harga secara parsial tidak berpengaruh terhadap kepuasan konsumen. Sedangkan Fiazisyah \& Purwidiani (2018) mengatakan ternyata dalam variabel harga terdapat pengaruh yang positif signifikan terhadap kepuasaan konsumen sama seperti Ezra Hendri Noto (2013) yang menyatakan terdapat bukti bahwa dan harga memiliki pengaruh positif yang signifikan terhadap kepuasan konsumen.

H1: Harga berpengaruh positif terhadap kepuasan konsumen.

Hidayati \& Setyorini (2013) menyatakan bahwa variabel kualitas layanan elektronik memiliki pengaruh positif signifikan terhadap kepuasan. Sama seperti penelitian Setyasworo \& Se (2012) mengatakan e-serqual berpengaruh positif terhadap kepuasan nasabah. Dalam pada penelitian Awaliyah \& Saino (2014) ini kualitas layanaan elektronik berdampak positif terhadap kepuasan konsumen. Sedangkan Menurut penelitian Kandulapati \& Bellamkonda (2014) menghasilkan bahwa e-servqual tidak mempunyai dampak yang besar terhadap kepuasan.

H2: Kualitas layanan elektronik berpengaruh positif terhadap kepuasan konsumen.

\section{METODE PENELITIAN}

Metode penelitian ini menjelaskan beberapa jenis penelitian yaitu riset kausalitas. Instrumen dalam penelitian ini memakai kuesioner dengan beberapa item yang ditanyakan untuk variabel harga, kualitas layanan elektronik dan kepuasan konsumen dengan sumberdata yaitu data primer yang disebarkan secara online melalui Whatsapps, Facebook serta Twitter. Populasi yang dipakai pada penelitian ini yaitu pada pengguna aplikasi Shopee baik laki maupun perempuan dengan umur 15 tahun lebih dan sudah pernah melakukan transaksi belanja menggunakan Shopee dalam 6 bulan 1 transaksi. Teknik sampling dalam penelitian ini menggunakan non-probability sampling. 
Oktavianus Chrisnamurti Sabda Putra Mediti. Analisis Pengaruh Harga dan Kualitas Layanan Elektronik terhadap Kepuasan Konsumen pada Pengguna Aplikasi Shopee

Metode sampling pada penelitian ini yang digunakan adalah judgmental sampling agar mempunyai beberapa elemen yang dapat sama seperti populasi yang sudah diteliti. Responden dalam penelitian disini berjumlah 200 responden yang ditambah dengan 10 persen dari total responden sebelumnya 200 menjadi 220 responden (Malhotra, 2017:369). Metode analisis ini dalam penelitian memakai analaisis regresi linier berganda dengan uji hipotesis terdiri dari uji $\mathrm{F}$, uji $\mathrm{T}$, dan koefisien determinasi (Ghozali, 2016).

\section{HASIL DAN PEMBAHASAN}

\section{Hasil Validitas dan Reliabilitas}

Hasil uji validitas dan reliabilitas dalam penelitian ini dapat dilihat pada tabel 2. Uji validitas dilakukan dengan cara menyebar angket ke 30 responden untuk menguji kevalidan dari setiap item pernyataan. Pengukuran kelayakan dari masing-masing item yang ditanyakan dan dilihat dari hasil korelasi antara item pernyataan terhadap nilai total. Jika $r$ hitung $>r$ tabel dan nilainya positif, maka dari itu pernyataan atau indikator itu dapat dinyatakan valid maka $r$ tabel dengan data sebanyak 30 adalah 0,361 (Ghozali,2016:53). Penelitian ini menghasilkan semua item yang ditanyakan mempunyai nilai $r$ hitung > nilai $r$ tabel, sehingga bisa item pernyataan instrument penelitian ini valid dan bisa dipakai untuk pengukuran hasil selanjutnya.

Hasil uji reliabilitas yang ada dalam penelitian ini yaitu juga kepada 30 responden yang sama seperti uji validitas. Penelitian ini dilakukan dengan bantuan program software SPSS 23.0 dengan cara mencari hasil cronbach alfa, dapat diarikan reliabel apabila nilai cronbach alpa $>0.70$. (Ghozali, 2016:48). Penelitian menghasilkan nilai dari Cronbach's Alpha setiap variabel nilainya $>0,70$ sehingga pernyataan yang dibuat untuk instrumen penelitian adalah reliabel serta bisa dipakai untuk alat pengukuran.

Tabel 2 menunjukan bahwa karakteristik responden frekuensi penelitian menunjukan responden dengan frekuensi pembelian 1 kali sebanyak $41(18,6 \%)$, frekuensi pembelian 2 kali sebanyak 32 $(14,5 \%)$, dan frekuensi pembelian >2kali sebanyak 147 (68,8\%). Berdasarkan hasil data tersebut diketahui bahwa responden dengan frekuensi $>2$ kali adalah yang mendominasi.

Karakteristik responden berdasarkan jenis kelamin menunjukan sebanyak 78 (35,5\%) responden berjenis kelamin laki-laki dan yang berjenis kelamin perempuan sebanyak 147 (64,5\%). Dengan kata lain, responden berjenis kelamin perempuan adalah yang mendominasi.

Responden yang berdasarkan usia menunjukan sebanyak 49 (22,3\%) responden berusia 15 -20 tahun, $150(68,2 \%)$ responden berusia 21-25 tahun, $15(6,8 \%)$ responden usia 26-30 tahun dan untuk responden berusia 31 tahun keatas sebanyak $6(2,7 \%)$. Sehingga, responden yang mendominasi merupakan responden yang berusia 21-25 tahun.

Karakteristik responden berdasarkan pekerjaan menunjukan sebanyak $25(10,9 \%)$ responden siswa, sebanyak125 (56.8\%) responden mahasiswa. Sebanyak $4(1,8)$ responden PNS, sebanyak $43(19,5)$ responden karyawan swasta, sebanyak $14(6,4 \%)$ responden wirausaha, sebanyak $2(0,9 \%)$ respondent ibu rumah tangga, dan sejumlah $8(3,7 \%)$ adalah responden lainnya. sehingga responden yang banyak mendominasi yaitu responden mahasiswa.

\section{Hasil Uji Asumsi Klasik}

Uji Normalitas pada penelitian ini dilakukan dengan analisis explore dan pengujian normal probability (Ghozali, 2016:154). Pengujian analisis explore menggunakan uji Kolmogorov-Smirnov dengan tingkat signifikasi 0,05. Jika Signifikansi > 0,05 maka data berdistribusi normal. Uji normalitas memakai uji kolmogorov-smirnov (K-S) dan yang memiliki nilai sebesar 0,05 dan signifikasi sebesar 0,200 lebih besar dari 0,05. Penelitian ini menunjukan hasil nilai uji KolmogrovSmirnov sebesar 0,055 dengan nilai signifikansi sebesar 0,200. Nilai signifikansi lebih besar dari 0,05. Sehingga, data berdistribusi normal. 
Tabel 1.

UJI VALIDITAS DAN RELIABILITAS

\begin{tabular}{|c|c|c|c|}
\hline Variabel & Item & Rhitung & Cronbach's Alpha \\
\hline \multirow[t]{8}{*}{ Harga (X1) } & $\mathrm{X} 1.1$ & 0,703 & 0,834 \\
\hline & $\mathrm{X} 1.2$ & 0,688 & \\
\hline & $\mathrm{X} 1.3$ & 0,656 & \\
\hline & $\mathrm{X} 1.4$ & 0,536 & \\
\hline & $\mathrm{X} 1.5$ & 0,682 & \\
\hline & $\mathrm{X} 1.6$ & 0,739 & \\
\hline & $\mathrm{X} 1.7$ & 0,730 & \\
\hline & $\mathrm{X} 1.8$ & 0,730 & \\
\hline \multirow[t]{10}{*}{ Kualitas Layanan Elektronik (X2) } & $\mathrm{X} 2.1$ & 0,552 & 0,838 \\
\hline & $\mathrm{X} 2.2$ & 0,610 & \\
\hline & $\mathrm{X} 2.3$ & 0,656 & \\
\hline & $\mathrm{X} 2.4$ & 0,708 & \\
\hline & $\mathrm{X} 2.6$ & 0,578 & \\
\hline & $\mathrm{X} 2.7$ & 0,582 & \\
\hline & $\mathrm{X} 2.8$ & 0,651 & \\
\hline & $\mathrm{X} 2.9$ & 0,694 & \\
\hline & $\mathrm{X} 2.10$ & 0,682 & \\
\hline & $\mathrm{X} 2.11$ & 0,678 & \\
\hline \multirow[t]{9}{*}{ Kepuasan Konsumen (Y) } & Y1.1 & 0,712 & 0,898 \\
\hline & $\mathrm{Y} 1.2$ & 0,798 & \\
\hline & Y1.3 & 0,640 & \\
\hline & Y1.4 & 0,793 & \\
\hline & Y1.5 & 0,753 & \\
\hline & Y1.6 & 0,769 & \\
\hline & $\mathrm{Y} 1.7$ & 0,742 & \\
\hline & Y1.8 & 0,772 & \\
\hline & Y1.9 & 0,721 & \\
\hline
\end{tabular}

Sumber: Hasil output SPSS 23

Uji multikolinieritas menunjukan nilai tolerance pada variabel harga ,602 dan kualitas layanan elektronik ,602 tidak kurang dari 0,1 dan nilai VIF variabel harga 1,660 dan kualitas layanan elektronik 1,660. maka,tidak ada yang lebih dari 10. Artinya, tidak ada multikolonearitas.

Uji heteroskedastisitas berfungsi untuk menguji adakah terjadi perbedaan variance dan residual dalam bentuk regresi. Pengujian heteroskedastisitas dengan melihatkan dari grafik plot antara dari nilai perkiraan varfiabel dependent yaitu ZPRED denan Residualnya SRESID. Jika ada pola tertentu, seperti titik-titik yang ada membentuk pola tertentu yang teratur maka menunjukan adanya heteroskedastisitas (Ghozali, 2016;134). Hasil dari uji heteroskedastisitas yang menggunakan grafik scatterplots mengartikan tidak ada pola yang sangat jelas dan titik-titiknya menyebar diatas dan di bawah linier 0 pada sumbu Y. Sehingga, tidak ada heteroskesdastisitas.

\section{Regresi Linier Berganda}

Hasil regresi linear berganda dapat dinyatakan dalam rumus (1). Nilai konstanta sebesar 2,547 artinya jika variabel independen dianggap konstan, maka nilai kepuasan konsumen pada aplikasi Shopee sebesar 2,547. Koefisien regresi harga yaitu 0,558 artinya semakin harga meningkat maka dari itu kepuasan juga akan naik atau tinggi dan koefisiensi regresi kualitas layanan elektronik yaitu 0,391, yang artinya setiap peningkatan kualitas layanan elektronik sebanyak 1000 dapat meningkatkan kepuasan konsumen sebesar 391 kali.

$\mathrm{Y}=2,547+0,558 \mathrm{X}_{1}+0,391 \mathrm{X}_{2}+\mathrm{e}$ 
Oktavianus Chrisnamurti Sabda Putra Mediti. Analisis Pengaruh Harga dan Kualitas Layanan Elektronik terhadap Kepuasan Konsumen pada Pengguna Aplikasi Shopee

Tabel 2.

KARAKTERISTIK RESPONDEN

\begin{tabular}{cccc}
\hline \multicolumn{2}{c}{ Karakteristik Responden } & Jumlah & Persentase (\%) \\
\hline Frekuensi Pembelian & 1 kali & 41 & $18,6 \%$ \\
& 2 kali & 32 & $14,5 \%$ \\
Frekuensi Pembelian & 2 kali & 147 & $68,8 \%$ \\
& 1 kali & 41 & $18,6 \%$ \\
& 2 kali & 32 & $14,5 \%$ \\
Usia & $>$ kali & 147 & $68,8 \%$ \\
& $15-20$ tahun & 49 & $22,3 \%$ \\
& $21-25$ tahun & 150 & $68,2 \%$ \\
Kelamin & $26-30$ tahun & 15 & $6,8 \%$ \\
& $>30$ tahun & 6 & $2,7 \%$ \\
& Laki-laki & 78 & $35,5 \%$ \\
& Perempuan & 142 & $64,5 \%$ \\
& Siswa & 24 & $10,9 \%$ \\
& Mahasiswa & 125 & $56,8 \%$ \\
& PNS & 4 & $1,8 \%$ \\
& Karyawan & 43 & $19,5 \%$ \\
& Swasta & 14 & $6,4 \%$ \\
& Wirausaha & 2 & $0,9 \%$ \\
& Ibu Rumah & & $3,7 \%$
\end{tabular}

Sumber: Data diolah

\section{Hasil Uji Statistik F}

Hasil uji F mengartikan bahwa nilai F hitung sebesar 152,186. Selain itu nilai probability 0.000 yang mengartikan lebih kecil dari 0.05 oleh dari itu dapat diartikan variabel harga dan kualitas layanan elektronik dengan serentak atau secara simultan memengaruhi variabel kepuasan konsumen.

\section{Hasil Uji Statistik t}

Hasil uji t berguna untuk mengetahui pengaruh signifikan variabel independen terhadap variabel dependen secara parsial. Hasil uji statistik t pengaruh harga dan kualitas layanan elektronik terhadap kepuasan konsumen disajikan pada tabel 3. Nilai t hitung variabel pada harga sebesar 0,000 dengan probabilitas nilai sebesar 7,799 lebih besar dari 0,05. Sehingga dapat disimpulkan harga memengaruhi positif terhadap kepuasan konsumen dan nilai $\mathrm{T}$ hitung dalam variabel kualitas layanan elektronik sebesar 0,000 dengan peluang signifikan sebesar 7,194 dan lebih besar dari 0.05. Artinya, kualitas layanan elektronik memengaruhi atau berpengaruh positif terhadap kepuasan konsumen. Variabel harga dan kualitas layanan elektronik terbukti berpengaruh positif terhadap kepuasan konsumen pada pengguna aplikasi Shopee.

\section{Hasil Koefisien Determinasi $\left(\mathbf{R}^{2}\right)$}

Penelitian ini koefisien determinasi $\left(\mathrm{R}^{2}\right)$ menunjukan hasil nilai adjusted $\mathrm{R}^{2}$ sebesar 0.580 . Nilai tersebut menunjukkan bahwa harga dan kualitas layanan elektronik $0.580=58 \%$ memengaruhi variabel dependen yaiu kepuasan konsumen pengguna aplikasi Shopee, sedangkan $42 \%$ sisanya dipengaruhi oleh variabel lainnya yang tidak ada dalam penelitian ini.

\section{Pengaruh Harga terhadap Kepuasan Konsumen}

Hasil penelitian menunjukan terdapat pengaruh positif dan yang sangat signifikan antara harga ke kepuasan konsumen. Artinya bahwa harga yang semakin sesuai dengan manfaat yang di terima oleh konsumen, oleh karena itu kepuasan konsumen kepada harga produk di shopee juga meningkat. Hal tersebut menunjukan bahwa hipotesis 1 terbukti. 


\section{Tabel 3. UJI STATISTIK T}

\begin{tabular}{ccc}
\hline Variabel & T & Sig. \\
\hline Harga & 7,799 & .000 \\
Kualitas Layanan Elektronik & 7,194 &, 000 \\
\hline Sumber: Output SPSS 23 & &
\end{tabular}

Hasil penelitian ini sesuai dengan penelitian Fiazisyah \& Purwidiani (2018) mengatakan bahwasannya harga memengaruhi hal positif terhadap kepuasan konsumen dan penelitian Isfahila, Fatimah, \& S (2018) juga mendukung yang menghasilkan harga berpengaruh signifikan positif terhadap kepuasan konsumen. Hasil dari penelitian ini tidak mendukung penelitian Shartykarini, Firdaus, \& Rusniati, (2016) yang menyatakan harga tidak berpengaruh signifikan terhadap kepuasan konsumen, dan juga tidak mendukung dari penelitian Hadita (2019) yang membuktikan pengaruh negatif harga terhadap kepuasan konsumen.

Penelitian yang dilakukan dalam mengukur variabel harga (X1) dengan menggunakan empat indikator yaitu indikator keterjangkauan harga, kesesuaian harga dengan kualitas produk, kesesuaian produk dengan manfaatnya, dan daya saing harga. Berdasarkan jawaban responden dalam indikator kesesuaian harga dengan kualitas produk, dalam item pertanyaan "Harga produk bervariasi sesuai dengan kualitas produk" adalah jawaban tertinggi. Hal tersebut memperlihatkan harga di shopee sudah sesuai. Responden perempuan dengan rentan umur 21-25 tahun yaitu yang sangat terlihat atau paling banyak dalam penelitian ini. Responden perempuan yang memiliki usia 21-25 tahun yang condong untuk menilai toko online melihat dari harga diaman harga sesuai dengan kualitas produk dan manfaatnya maka responden cenderung akan merasa puas berbelanja menggunakan aplikasi Shopee.

Responden dengan jenis kelamin perempuan rentan umur 21-25 tahun yaitu yang sangat mendominasi dalam penelitian ini. Responden perempuan yang memiliki umur 21-25 tahun yang condong menilai toko online dari sudut pandang harga di mana harga sesuai dengan kualitas produk dan manfaatnya maka responden cenderung akan merasa puas berbelanja menggunakan aplikasi Shopee.

\section{Pengaruh Kualitas Layanan Elektronik terhadap Kepuasan Konsumen}

Analisis yang telah dilaksanakan oleh peneliti, peneliti mendapatkan hasil yang menunjukann adanya pengaruh positif dan signifikan antara kualitas layanan elektronik dengan kepuasan konsumen pengguna aplikasi shopee. Hasil dalam penelitian ini sesuai dengan teori Parasuraman et al., (2005) bahwa e-service quality (kualitas layanan elektronik) sebagai sejauh mana sebuah situs web atau aplikasi mampu memfasilitasi kegiatan belanja yang dilakukan konsumen di situs tersebut dapat berjalan efektif dan efisien, serta hal-hal mengenai pengiriman produk dan layanan. Artinya sebuah pelayanan itu memiliki sifat komperhensif yang mencakup kedua aspek yaitu dari pra-layanan dan post-situs web. Contohnya seperti aplikasi Shopee yang harus memberikan layanan yang dapat membuat para pengguna baik penjual maupun pembeli dapat merasakan kepuasan dalam menggunakannya.

Hasil dalam penelitian ini telah mendukung penelitian Hidayati \& Setyorini (2013) yang menyatakan bahwa kualitas layanan elektronik yang diberikan oleh kantor pos.apk sudah terpenuhi kebutuhan pelanggan tersebut dan penelitian Setyasworo \& Se (2012) yang menghasilkan kualitas layanan elektronik berpengaruh positif terhadap kepuasan nasabah. Namun, hasil penelitian ini bertolak belakang dengan hasil penelitian Candra \& Juliani (2018) yang gagal membuktikan pengaruh kualitas layanan elektronik terhadap kepuasan pelanggan.

Produk atau jasa yang berkualitas mempunyai spesifikasi yang sesuai dengan apa yang dibutuhkan konsumen sehingga mampu membuat konsumen merasa puas, hal ini akan mendorong para konsumennya untuk merasakan kepuasan dari kualitas layanan elektroniknya yang diterima. Sebagai contohnya shopee akan selalu menyimpan dan melindungi setiap informasi data pribadi dari pengguna 
Oktavianus Chrisnamurti Sabda Putra Mediti. Analisis Pengaruh Harga dan Kualitas Layanan Elektronik terhadap Kepuasan Konsumen pada Pengguna Aplikasi Shopee

sebagai bentuk kebijakan privasi yang berkomitmen secara nyata dari Shopee dan Shopee selalu terbuka dengan kritik dan saran yang di berikan oleh konsumen agar Shopee kedepannya menjadi lebih baik.

Penelitian ini mengukur dari variabel kualitas layanan elektronik terhadap kepuasan konsumen menggunakan 4 indikator meliputi effisiensi (efficiency), pemenuhan (fulfillment), ketersediaan sistem (system availability) dan privasi (privacy) . Berdasarkan dari salah satu jawaban responden dengan indikator efisiensi (efficiency), dengan item pertanyaan "Shopee memudahkan saya dalam mencari apa yang saya butuhkan" adalah jawaban tertinggi. Hal tersebut memperlihatkan Shopee memiliki sistem yang sudah sesuai dengan harapan konsumen pengguna aplikasi Shopee.

Responden mahasiswa dengan umur 21-25 tahun adalah yang mendominasi dalam penelitian ini. Responden tersebut cenderung cepat merasakan kepuasan setelah berbelanja jika harapannya terkait kualitas layanan elektronik maupun produk yang diinginkan sesuai.

\section{KESIMPULAN}

Variabel harga berpengaruh positif terhadap kepuasan konsumen pada pengguna aplikasi Shopee dan variabel kualitas layanan elektronik juga berpengaruh positif terhadap kepuasan konsumen pada pengguna aplikasi Shopee. Penelitian selanjutnya dapat melibatkan kelompok usia lebih dari 31 tahun, menggunakan angket secara online, offline, dan wawancara untuk mendapatkan data yang lebih sesuai dengan kenyataan, dan melibatkan variabel kualitas produk, loyalitas pelanggan, serta promosi.

\section{DAFTAR PUSTAKA}

Andrew, M. (2019). E-Service Quality and Brand Image on Buying Interest: A Study of E-Service Quality and Brand Image on Shopee E-Service Quality dan Citra Merek terhadap Minat Beli: Studi E-Service Quality dan Citra Merek Shopee. Jurnal Sekretaris \& Administrasi Bisnis (1), 23-38.

Candra, S., \& Juliani, M. (2018). Impact of E-Service Quality and Customer Value on Customer Satisfaction in LocalBrand. Binus Business Review, 9(2), 125. https://doi.org/10.21512/bbr.v9i2.4650

Cnnindonesia.com. 2020. Tren dan Peluang Industri E-Commerce di Indonesia 2020. (https://www.cnnindonesia.com/teknologi/20200205204206-206-472064/tren-dan-peluangindustri-e-commerce-di-indonesia-2020. diakses pada 6 Februaru 2020)

Cronin, J. J., Brady, M. K., \& Hult, G. T. M. (2000). Assessing the effects of quality, value, and customer satisfaction on consumer behavioral intentions in service environments. Journal of Retailing, 76(2), 193-218. https://doi.org/10.1016/S0022-4359(00)00028-2

Engel, J. F., Blackwell, R. D., \& Miniard, P. W. (1995). Perilaku Konsumen. Jakarta: Bina Rupa Aksara.

Ezra Hendri Noto, L. H. (2013). Analisis Pengaruh Harga Produk Dan Kualitas Produk Terhadap Kepuasan Pelanggan. Journal of Chemical Information and Modeling, 53(9), 1689-1699. https://doi.org/10.1017/CBO9781107415324.004

Fiazisyah, A., \& Purwidiani, N. (2018). Pengaruh Kualitas Produk, Harga, Dan Kualitas Pelayanan Terhadap Kepuasan Konsumen Restoran Cepat Saji KFC Basuki Rahmat Surabaya. Boga, 7(2), $178-187$.

Ghozali, Imam. (2016b). Aplikasi Analisis Multivariete dengan Program IBM SPSS 23 (Edisi 8; P. Harto, ed.). Semarang: Badan Penerbit Universitas Diponegoro. 
Hadita. (2019). Kata Kunci: Promosi, Harga, Kepuasan Pelanggan The Promotions And Prices On Customer Satisfaction 's Fast Food Restaurant. Jurnal Bisnis Dan Manajemen, 3, 25-38.

Hermina, T., \& Pauzi, I. (2017). Pengaruh Harga Dan Kualitas ProdukTerhadap Kepuasan Konsumen Pengguna Smartphone Sony Pada PT. Maju Jaya Cicaheum Bandung. Jurnal Wacana Ekonomi, $16(02), 1-8$.

Hidayati, Z. N., \& Setyorini, R. (2013). Pengaruh E-Service Quality terhadap Kepuasan Pelanggan Sebagai Pengguna Kantor Pos.Apk. Journal of Chemical Information and Modeling, 53(9), 1689-1699. https://doi.org/10.1017/CBO9781107415324.004

Inet.detik.com. 2019. Fakta Persaingan Tokopedia, Bukalapak, Shopee, Blibli cs. (https://inet.detik.com/cyberlife/d-4706085/fakta-persaingan-tokopedia-bukalapak-shopeeblibli-cs. diakses pada 14 September 2019).

Iprice.co.id. 2019. Fine Out E-Commerce Competition in Indonesia. (https://iprice.co.id/insights/mapofecommerce/en/. diakses pada September 2019)

Isfahila, A., Fatimah, F., \& S, W. E. (2018). Pengaruh Harga, Desain, Serta Kualitas Produk Terhadap Kepuasan Konsumen. Jurnal Sains Manajemen Dan Bisnis Indonesia, 8(2), 211-227. https://doi.org/10.32528/jsmbi.v8i2.1790

Kandulapati, S., \& Bellamkonda, R. S. (2014). E-service quality: a study of online shoppers in India. American Journal of Business, 29(2), 178-188. https://doi.org/10.1108/ajb-05-2013-0030

Kotler, P. dan A. (2008). Prinsip-Prinsip Pemasaran (Jilid 1). Jakarta: Erlangga.

Media.neliti.com. 2015. Pengaruh Promosi Dan Harga Terhadap Keputusan Pembelian Surat Kabar Harian Suara Merdeka. (https://media.neliti.com/media/publications/187629-ID-pengaruhpromosi-dan-harga-terhadap-kepu.pdf. diakses pada tahun 2015)

NewsDetik. 2019. Pesan Shopee sudah dibatalkan masih tertagih kartu kredit. (https://news.detik.com/suara-pembaca/d-3993990/pesanan-shopee-sudah-dibatalkan-masihtertagih-kartu-kredit. diakses pada 3 mei 2018).

Parasuraman, A. Zeithaml, V. A., Malhotra, A. (2005). E-SerQual A Multiple-Item Scale for Assessing Electronic Service Quality. Journal of Service Research, 7(3), 213-233.

Rhee'q, V. (2012). Cara Gampang Cari Duit di Internet. Jakarta: PT. Gramedia Pustaka Utama.

Sebti Atul Awaliyah, \& Saino. (2014). Pengaruh Kualitas Layanan Terhadap Kepuasan Pelanggan Online ( Studi Pada Dkpop Shop ). Jurnal Pendidikan Tata Niaga, 2, 19.

Setyasworo, H., \& Se, M. A. (2012).Pengaruh Kualitas Pelayanan Elektronik terhadap Nasabah Pengguna Internet Banking Bank Mandiri Cabang Bandung Tahun 2012. Skripsi Manajemen Bisnis \& Informatika. Telkom University

Shartykarini, S., Firdaus, R., \& Rusniati. (2016). Pengaruh Harga, Kualitas Produk dan Kualitas Layanan Terhadap Kepuasan Pelanggan dalam Membentuk Loyalitas Pelanggan (Studi Pengunjung Cafe di Banjarbaru). Jurnal Wawasan Manajemen, 3(4).

Sumarwan, Ujang. (2014). Perilaku Konsumen Teori dan Penerapannya dalam Pemasaran (Edisi 2). Bogor: Ghalia Indonesia.

Swastha, Irawan. (2005). Manajemen Pemasaran Modern. Yogyakarta: Liberty. 
Oktavianus Chrisnamurti Sabda Putra Mediti. Analisis Pengaruh Harga dan Kualitas Layanan Elektronik terhadap Kepuasan Konsumen pada Pengguna Aplikasi Shopee

Tjiptono, F., \& Chandra, G. (2012). Pemasaran Strategi (Edisi 2). Yogyakarta: Andi.

Wibowo, A., \& Purwohandoko. (2019). Pengaruh Pengetahuan Investasi, Kebijakan Modal Minimal Investasi, Dan Pelatihan Pasar Modal Terhadap Minat Investasi (Studi Kasus Mahasiswa FE Unesa Yang Terdaftar Di Galeri Investasi FE Unesa). Jurnal Ilmu Manajemen, 7(1), 192-201. 